\title{
The sources of granitic melt in Deep Hot Zones
}

\author{
Catherine Annen, Jonathan D. Blundy and R. Stephen J. Sparks
}

\begin{abstract}
A Deep Hot Zone develops when numerous mafic sills are repeatedly injected at Moho depth or are scattered in the lower crust. The melt generation is numerically modelled for mafic sill emplacement geometries by overaccretion, underaccretion or random emplacement, and for intrusion rates of 2, 5 and $10 \mathrm{~mm} / \mathrm{yr}$. After an incubation period, melts are generated by incomplete crystallisation of the mafic magma and by partial melting of the crust. The first melts generated are residual from the mafic magmas that have low solidi due to concentration of $\mathrm{H}_{2} \mathrm{O}$ in the residual liquids. Once the solidus of the crust is reached, the ratio of crustal partial melt to residual melt increases to a maximum. If wet mafic magma, typical of arc environments, is injected in an amphibolitic crust, the residual melt is dominant over the partial melt, which implies that the generation of I-type granites is dominated by the crystallisation of mafic magma originated from the mantle and not by the partial melting of earlier underplated material. High ratios of crustal partial melt over residual melt are reached when sills are scattered in a metasedimentary crust, allowing the generation of S-type granites. The partial melting of a refractory granulitic crust intruded by dry, high-T mafic magma is limited and subordinate to the production of larger amount of residual melt in the mafic sills. Thus the generation of A-type granites by partial melting of a refractory crust would require a mechanism of selective extraction of the A-type melt.
\end{abstract}

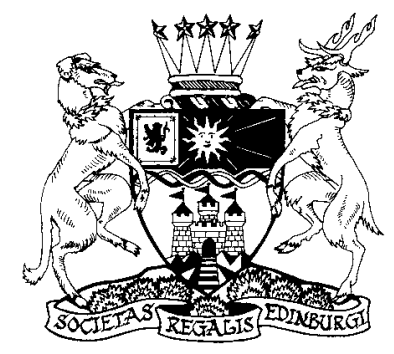

KEY WORDS: crust melting, emplacement geometry, heat transfer, intrusion rate, mafic sills, magma generation, numerical simulation, partial melt, residual melt

Granitic magmas can originate either from the differentiation of mafic magmas, or from the partial melting of the crust. In some cases, as for the High Himalayan Leucogranites, the mechanisms invoked for the partial melting of the crust are thickening of a crust rich in radiogenic elements (England \& Thompson 1984), shear heating along major faults (England et al. 1992; Harrison et al. 1998), and heat refraction at the interface of rocks with contrasting conductivities (Jaupart \& Provost 1985). However, many granitoids around the world are associated with mafic igneous rocks as enclaves or sheeted intrusions (e.g. Barbarin 2005; Blundy \& Sparks 1992) and mafic magmas play a fundamental role in silicic melt generation either as parents or as heat and fluid sources for crustal melting.

Chappell \& White (2001) distinguish between S-type granites and I-type granites. In the Lachlan Fold belt (Australia) these two contrasting types were defined, based on geochemical, mineralogical and isotopic differences, although there can be overlap in chemical and isotopic compositions. According to Chappell \& White (2001), relative to I-type granites, S-type granites have higher molar $\mathrm{Al} /(\mathrm{Na}+\mathrm{Ca}+\mathrm{K})$ ratios. The explanation proposed by Chappell \& White (2001) for these characteristics is that S-type granites originate by partial melting of supra-crustal metasedimentary rocks, depleted in $\mathrm{Na}$ and $\mathrm{Ca}$ by sedimentary processes, and I-type granites are generated by partial melting of source rocks of intermediate to mafic igneous origin. The relative homogeneity of large volumes of I-type granite is attributed to their origin by partial melting of rocks formed in earlier episodes of crustal underplating (Chappell \& White 1984). However, according to Patiño Douce (1999), except for peraluminous leucogranites, other types of granitic magmas are not pure crustal melts and have a significant basaltic component.

Arc magmatism produces considerable volumes of granites, as exemplified by the American cordilleran batholiths. Although isotope based models are non-unique, they are widely used to determine the source of igneous rocks. For example, the isotope signatures of the Mesozoic to Tertiary Andean granites indicate a dominant mantle component (Lucassen et al. 2004). Sr, Nd, and O isotope data for the Sierra Nevada granitoid batholith (California) suggest hybrid magmas with mixed mantle and crustal sources (DePaolo 1981a; Domenick et al. 1983; Kistler et al. 1986; Kistler \& Peterman 1973). In the central Sierra Nevada batholith the similar ages of the mafic intrusions and the granodiorites (Coleman et al. 1995) and the chemical similarity between the gabbros and granites (Sisson et al. 1996) suggest that they are genetically linked. Magma mixing has been proposed as an important process in granite generation (Patiño Douce 1999; Reid et al. 1983; Sisson et al. 1996). The isotopic similarities between deep mafic and ultramafic xenoliths sampled by Miocene volcanic rocks through the central part of the Sierra Nevada batholith and the granodiorites suggest that the xenoliths are either restites or cumulates resulting from granite generation (Ducea \& Saleeby 1998).

Metaluminous, alkaline and peralkaline granites, characteristic of anorogenic tectonic environments, have been defined as A-type granites (Collins et al. 1982). A-type granites correspond to a wide variety of rocks and it is possible that different processes play a role in their generation in different circumstances (Clemens et al. 1986). A-types granites have been defined as anhydrous, but Clemens et al. (1986) showed experimentally that the melt $\mathrm{H}_{2} \mathrm{O}$ content of the metaluminous Watergums A-type Granite was between $2 \cdot 4 \mathrm{wt} \%$ and $4 \cdot 3 \mathrm{wt} \%$. The mechanisms proposed for generation of A-type granites include the fractionation of mantle-derived melts (Bonin 2007; Foland \& Allen 1991; Kerr \& Fryer 1993; Turner \& Foden 1996; Turner et al. 1992), the deep partial melting of a melt-depleted I-type source (Clemens et al. 1986; Collins et al. 1982; Whalen et al. 1987), and the low-pressure, high temperature fluid-absent melting of hornblende and biotite bearing granitoids (Patiño Douce 1997). 


\section{Melt generation in Deep Hot Zones}

Annen et al. (2006) proposed a model of intermediate and silicic melt generation in Deep Hot Zones, based on numerical simulations of heat transfer and the constraints of phase equilibria. In this model, mafic sills are successively emplaced in the lower crust at the mantle-crust interface or at higher levels in the crust. The first emplaced sills completely solidify and transfer their heat to the crust, which progressively rises in temperature. After an incubation period that depends on sill emplacement rate, the temperature at the injection depth reaches that of the mafic magma solidus. Subsequent mafic intrusions do not completely crystallise and residual melts start to accumulate. Partial melting of the crust can start when the fluid-absent solidus of the particular crustal rock types is reached. When enough heat has been advected by the mafic magma, melts are simultaneously generated by incomplete crystallisation of the mafic magma, by partial melting of old crust and by remelting of formerly emplaced mafic intrusions. AFC (assimilation and fractional crystallisation) and MASH (melting, assimilation, storage and homogenisation) processes can occur in the hot zone (DePaolo 1981b; Hildreth \& Moorbath 1988). It is noted that fluid-present crustal melting can also be triggered by release of volatiles from the basaltic intrusions, but this topic is not developed in the present paper.

The mantle-lower crust boundary is a likely level for mafic magmas to stall because it acts as a rheological trap. For example a $10 \mathrm{~km}$ thickness of mafic rocks in the Ivrea Zone (European Alps) has been interpreted as basaltic underplating of the lower crust (Quick et al. 1994). The presence of deep ultramafic roots, below the Sierra Nevada, foundering into the underlying mantle has been inferred from seismic images (Zandt et al. 2004). In contrast, mafic or ultramafic bodies do not form a significant component of the upper crust.

The deep crust is a favourable location for generation of silicic melts. Temperature increases with depth and the higher the temperature the easier it is to generate evolved residual melts and reach conditions for partial melting. In regions of high heat flow and sustained magma flux through the crust, the temperatures in the lower crust can exceed the solidi of both the mafic magmas and the crust. In the deep crust, $\mathrm{H}_{2} \mathrm{O}$, concentrates in melts residual from mafic magma crystallisation and remains dissolved due to high pressure. As a consequence, evolved melts have low viscosities and densities. These buoyant, low-viscosity melts can be extracted by compaction on geologically reasonable timescales of $10^{4}-10^{6}$ years (McKenzie 1984) and more rapidly if segregation by non co-axial deformation is involved (e.g. Brown 1994; Petford 2003). Volume changes during fluid absent melting can also provide a driving force for melt segregation (Rushmer 2001). The released melts can ascend rapidly (on timescales of hours or days) to supply the formation of granitoid plutons in the middle and upper crust (Clemens \& Mawer 1992; Petford et al. 1993).

The objective of this present paper is to present new modelling data on the respective contribution in the generation of granitic melts in Deep Hot Zones of the partial melting of the crust and of the crystallisation of mafic magmas and to discuss the results with reference to some general models of granite generation that have been described in the literature. It is not possible to test the numerical model with all the possible source rocks that have been proposed for the various granite types. Therefore, tests were carried out on three different common crustal lithologies, covering the range of possible crust fertilities from a highly fertile pelitic crust to a very refractory granulitic crust. The intermediate case is an amphibolitic crust.

The respective contribution of mafic magma crystallisation and crustal melting is quantified using numerical simulations of the incremental addition of mafic sills into the crust. The temperatures and melt fractions of the hot zone are calculated with equations of heat transfer, including sensible heat and latent heat. The model is one-dimensional and uses forward finite differences and iterative approximations encoded in the Delphi language. Details of the numerical simulations and of the values of input parameters are found in Annen \& Sparks (2002) and Annen et al. (2006). In the present paper, the melt generated by incomplete crystallisation of the mafic magma (mantle source) will be called 'residual melt' and the melt generated by partial melting of the crust (crustal source) will be called 'partial melt'.

\section{Progressive emplacement of mafic magma}

Models of heat transfer between mafic magma and crust have typically involved a single mafic sill instantaneously emplaced in contact with crustal rocks (Barboza \& Bergantz 1996; Bergantz 1989; Huppert \& Sparks 1988; Jackson et al. 2003; Raia \& Spera 1997). The amount of crustal melt generated in these models depends on the thickness of the mafic sill, and on the initial temperatures and physical properties of the mafic magma and crust. However, mafic intrusion into the crust is more likely to be incremental with accretion of successive smaller intrusions. Petford \& Gallagher (2001), Annen \& Sparks (2002) and Annen et al. (2006) have modelled the heat transfer between successive mafic sills and crustal rocks, and Dufek \& Bergantz (2005) simulated intrusions of randomly orientated dykes. These models indicate that the volume of melt produced by the fluid-absent melting of an amphibolitic lower crust is more than one order of magnitude smaller than the volume of mafic magma needed as a heat source. However, Annen \& Sparks (2002) and Annen et al. (2006) showed that significant quantities of melt are produced by incomplete crystallisation of the intruded mafic magma.

In a system of accreting sills, the amount of melt generated depends on the initial temperature of the crust (i.e. of the position of the sill on the geotherm), and on the physical properties of mafic magmas and crustal rocks. In the model of multiple intrusions, the rate of crustal melt generation is also controlled by the mafic magma emplacement rate and by the physical position of successive sills relative to each other.

In the present paper, three types of sill emplacement geometries are simulated (Fig. 1):

1. Overaccretion: all sills are emplaced at a fixed level above the former one;

2. Underaccretion: each sill is emplaced below the former one and the sill emplacement level deepens with time;

3. Random emplacement: the level of emplacement is random between an upper and lower limit.

In each case, space for each new sill is made by moving down the rocks below it. In the case of overaccretion, and partly in the case of random emplacement, formerly injected sills are moving down along the geotherm when a new sill is intruded (Fig. 1).

\section{The sources of melts}

A critical parameter in the model is the respective fertility of mafic magma and crust, described by relationships between temperatures, pressures, and melt fractions. The models were 

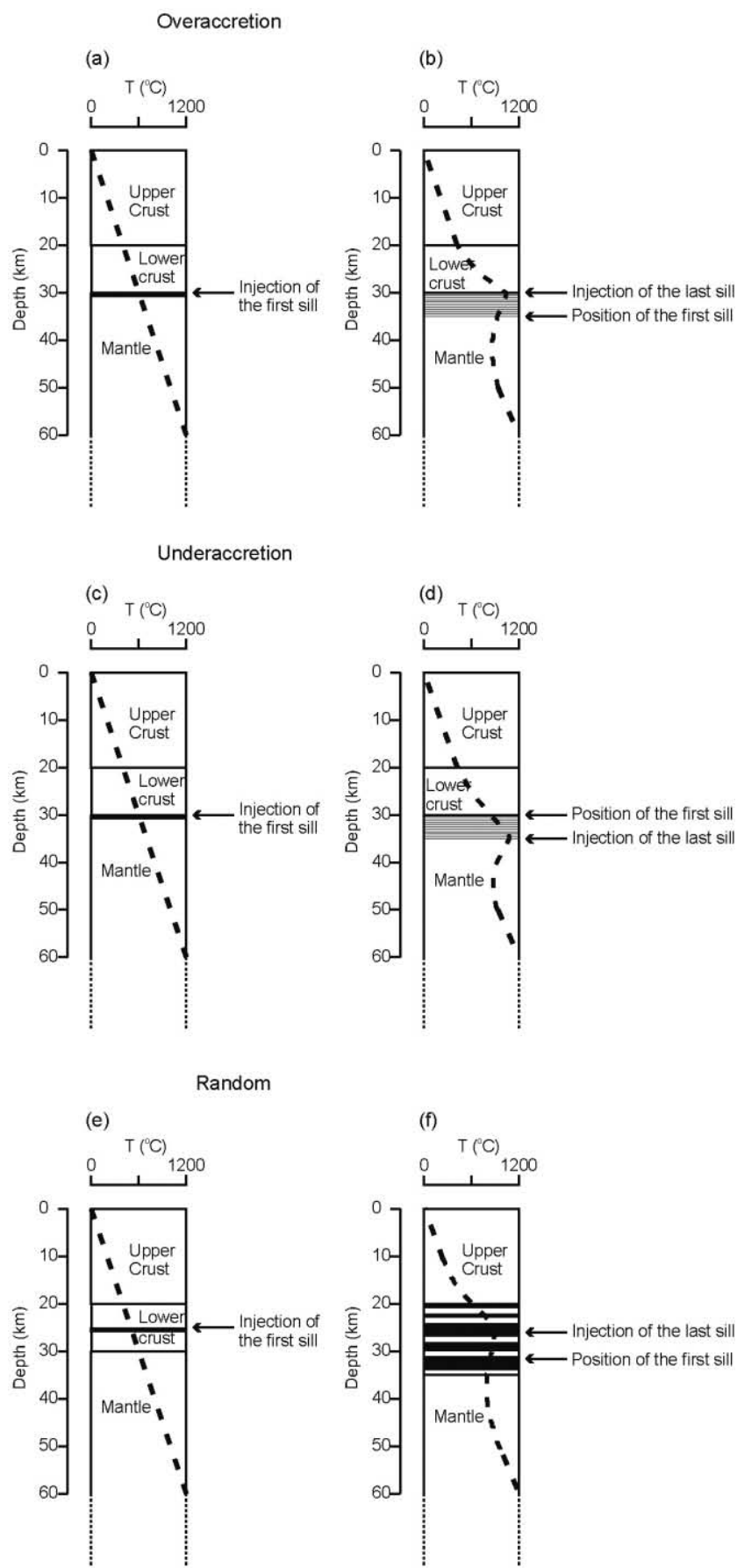

Figure 1 Schematic representation of the emplacement of the mafic sills in the modelled hot zone. Mafic sills are emplaced by overaccretion $(\mathrm{a}, \mathrm{b})$, underaccretion $(\mathrm{c}, \mathrm{d})$, or at random throughout the lower crust (e, f). The system is shown at the onset of intrusion (a, c, e) and after the emplacement of a series of sills (b, d, f). Each new sill volume is accommodated by downward displacement of the crust, previous sills and mantle below the injection level. Temperature is represented by the dashed line. The initial temperature is determined by a geothermal gradient of $20^{\circ} \mathrm{C} \mathrm{km}^{-1}$. The temperature of individual sills evolves with time and with their evolving position along the geotherm. The temperatures at the Earth's surface and at $60 \mathrm{~km}$ depth are fixed.

run with a mafic magma injected at $1285^{\circ} \mathrm{C}$, with an $\mathrm{H}_{2} \mathrm{O}$ content of $2.5 \mathrm{wt} \%$, and with a mafic magma injected at $1346^{\circ} \mathrm{C}$, with an $\mathrm{H}_{2} \mathrm{O}$ content of $0.3 \mathrm{wt} \%$. The first case represents, for example, wet primitive arc basalts or alkali basalts in continental and some intraplate volcanoes, while the second represents primitive hot dry basalts that can be found in diverse tectonic settings. The mafic magma is assumed to intrude at its liquidus temperature. The temperature-melt

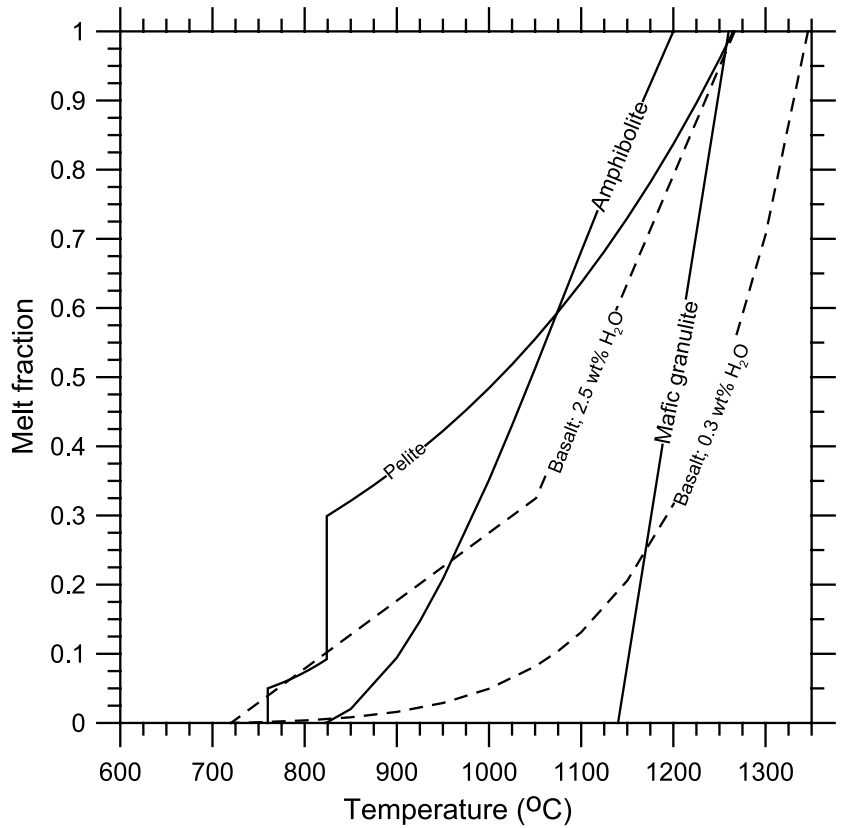

Figure 2 Modelled melt fraction vs temperature curves at $10 \mathrm{kbar}$ for basalt with 0.3 and $2.5 \mathrm{wt} \% \mathrm{H}_{2} \mathrm{O}$, and pelite, amphibolite, and a dry mafic granulite. The curve for basalt with $2.5 \mathrm{wt} \% \mathrm{H}_{2} \mathrm{O}$ have a slope of $0.325^{\circ} \mathrm{C}^{-1}$ between the liquidus temperature and the temperature of amphibole crystallisation $T_{a}$, based on extrapolation of experimental data from Müntener et al. (2001). The curves kink at $\mathrm{T}_{\mathrm{a}}$ to fall linearly to Ts, the $\mathrm{H}_{2} \mathrm{O}$-saturated mafic magma solidus. The curve for basalt with $0.3 \mathrm{wt} \% \mathrm{H}_{2} \mathrm{O}$ is exponential to account for the low fertility of a dry mafic magma. The amphibolite curve is from Petford and Gallagher (2001). The pelite curve is based on the model of Clemens \& Vielzeuf (1987). The mafic granulite curve is based on Green (1982) and Mysen (1981) for anhydrous basalt.

fraction curves were parameterised using experimental data (Müntener et al. 2001; Sisson et al. 2005) and the equation proposed by Wood (2004) for the relationship between $\mathrm{H}_{2} \mathrm{O}$ content and liquidus temperature. For the mafic magma with $2.5 \mathrm{wt} \% \mathrm{H}_{2} \mathrm{O}$, the temperature-melt fraction relationships are linear, with an inflexion at the temperature of amphibole crystallisation (Fig. 2). The equations describing the temperature-melt fraction curves can be found in Annen et al. (2006). The liquidus and the amphibole crystallisation temperatures are estimated by extrapolation of the Müntener et al. (2001) data for a pressure of $12 \mathrm{kbar}$ and an $\mathrm{H}_{2} \mathrm{O}$ content of $2.5 \mathrm{wt} \%$ at $1285^{\circ} \mathrm{C}$ and $1075^{\circ} \mathrm{C}$, respectively. The role of pressure on melt productivity is taken into account by modifying the liquidus temperature by $9^{\circ} \mathrm{C} / \mathrm{kb}$ and the amphibole crystallisation temperature by $12^{\circ} \mathrm{C} / \mathrm{kb}$ (Foden \& Green 1992). For mafic magma with $0.3 \mathrm{wt} \% \mathrm{H}_{2} \mathrm{O}$, an exponential curve is adopted to account for the lower fertilities of $\mathrm{H}_{2} \mathrm{O}$-poor mafic magmas (Fig. 2). The solidus temperatures for both types of mafic magmas are taken as $720^{\circ} \mathrm{C}$, because $\mathrm{H}_{2} \mathrm{O}$ concentrates in the residual melt during mafic magma crystallisation and the solidus corresponds to the $\mathrm{H}_{2} \mathrm{O}$-saturated basalt solidus (Liu et al. 1996).

Three crust compositions are modelled: a dry mafic granulite, an amphibolite and a pelite. The mafic granulite represents a dehydrated refractory lower crust. The mafic granulite melt-temperature curves are linear with solidus and liquidus temperatures based on Mysen (1981) and Green (1982). The amphibolite composition (Fig. 2) is taken from Petford \& Gallagher (2001). The liquidus and solidus temperatures are modified for pressures different from $10 \mathrm{kbar}$ by $6{ }^{\circ} \mathrm{C} / \mathrm{kbar}$ (Foden \& Green 1992). The temperature-melt fraction curve for the pelite is based on the theoretical models of Clemens \& 
Vielzeuf (1987). The modelled pelite contains $1.23 \mathrm{wt} \% \mathrm{H}_{2} \mathrm{O}$ bound in $10 \%$ muscovite and $20 \%$ biotite (Clemens \& Vielzeuf 1987). Steps in the curves correspond to the breakdown of muscovite and biotite. Between those steps the curves are exponential. The temperatures for breakdown of muscovite and biotite at $10 \mathrm{kbar}$ are $760^{\circ} \mathrm{C}$ and $860^{\circ} \mathrm{C}$ and are modified with pressure at a rate of $12^{\circ} \mathrm{C} / \mathrm{kb}$.

The incubation time is defined as the time interval between the intrusion of the first mafic sill and the beginning of silicic melt formation. Which is produced first, mafic magma residual melt or crust partial melt, depends on the respective solidus temperatures of the emplaced mafic magma and crustal rocks. In the present model, at a depth of $30 \mathrm{~km}(\mathrm{P} \approx 10 \mathrm{kbar})$ the solidus of the mafic magma is lower than the solidus of the crust (Fig. 2). Thus the incubation time for the production of residual melt from the mafic magma is always shorter than the incubation time for fluid-absent melting of the crust. The incubation times for mantle and crustal melts strongly depend on the mafic magma intrusion rate. The mafic magma intrusion rate is calculated by dividing the thicknesses of sills by the time interval between intrusions of sills. As long as this time interval is small compared to the total time, the exact thickness and time interval is unimportant, and the rate of melt generation is controlled by the average mafic magma intrusion rate (Annen \& Sparks 2002). For reasons of computing efficiency, the thickness of the modelled sills is $50 \mathrm{~m}$. Intrusion rates of 10 , 5 , and $2 \mathrm{~mm} / \mathrm{yr}$ (corresponding to time intervals between sill of 5000,10000 , and 25000 yrs respectively) are tested corresponding to realistic rates based on estimates of magma productivities (Crisp 1984; Dimalanta et al. 2002; Shaw 1985; White et al. 2006). At the end of the simulation, $16 \mathrm{~km}$ of mafic magma have been emplaced which corresponds to simulation durations of 1.6 Myr, 3.2 Myr and $8 \mathrm{Myr}$ depending on the intrusion rates. Evidence for large thicknesses of mafic magma accumulating at the base of the crust is discussed later. The mafic magma intrusion rate also controls the time interval between the beginning of residual melt accumulation and the beginning of crustal melt accumulation. Results, involving the emplacement of mafic magma with $2.5 \mathrm{wt} \% \mathrm{H}_{2} \mathrm{O}$, are detailed first, for different mafic magma emplacement geometries. The case of mafic magma with $0.3 \mathrm{wt} \% \mathrm{H}_{2} \mathrm{O}$ is described later.

\subsection{Mafic magma emplacement by overaccretion}

For overaccretion, sills are emplaced at a fixed depth and the temperature maximum is close to the mafic magma-crust contact (Fig. 3). The incubation times strongly depend on the mafic magma intrusion rate (Fig. 4). The differences in incubation time between the residual and partial melts decreases with crust fertility (Fig. 5), reflecting the decrease in differences between the solidi of the mafic magma and the crust (Fig. 2). The differences in residual and partial melt incubation times also depend on mafic magma emplacement rates (Fig. 5). For example, for a mafic magma intrusion rate of $2 \mathrm{~mm} / \mathrm{yr}$ and an amphibolitic crust, the difference in incubation times is tens of thousands of years. However, for high mafic magma intrusions rates $(10 \mathrm{~mm} / \mathrm{yr})$, the difference in incubation times is of ten of thousands of years (Fig. 5b).

The total volume of melt generated is equal to the integration of the melt fraction over the thickness of partially molten material. As soon as the temperature of the crust exceeds the solidus of the mafic magma, the total volume of residual melt increases with each sill that is added to the hot zone. The quantity of residual melts in the mafic sills also increases with time due to an increase in the melting degree as the temperature of the hot zone raises. Thus the rate of residual melt generation is controlled by the intrusion rate. In contrast, the (a)

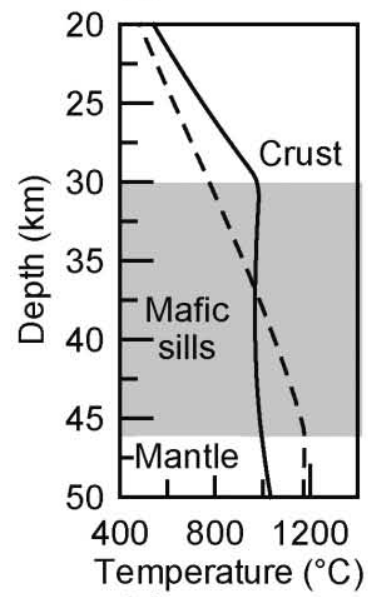

(c)

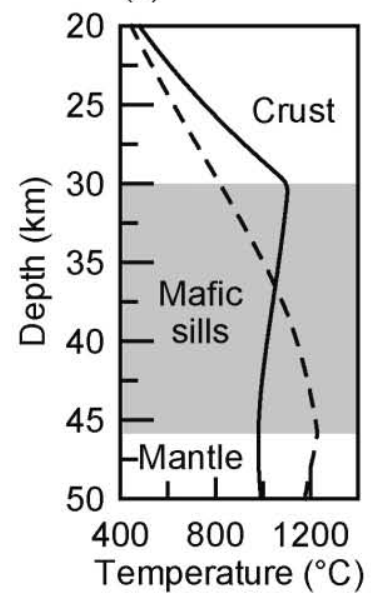

(e)

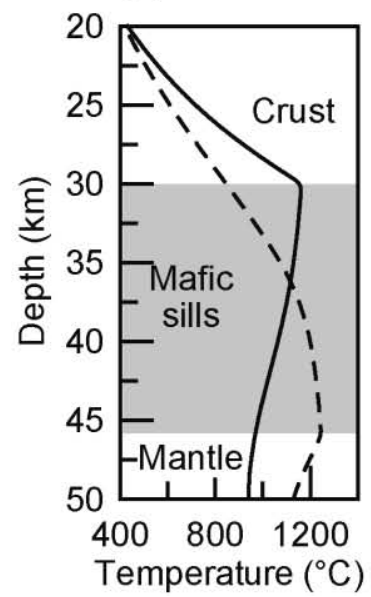

(b)

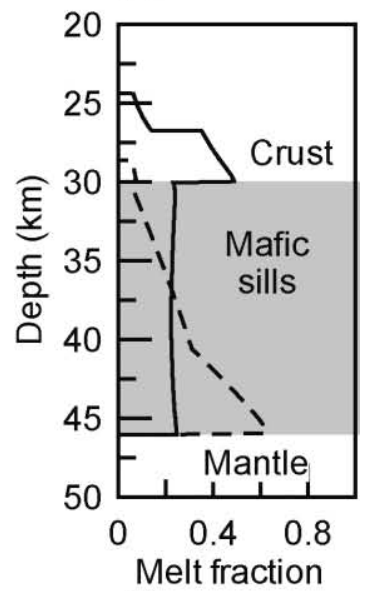

(d)

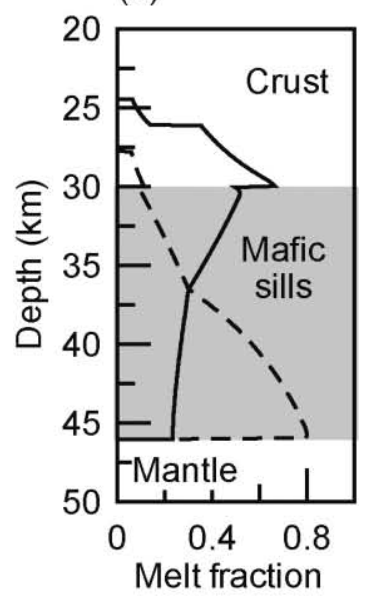

(f)

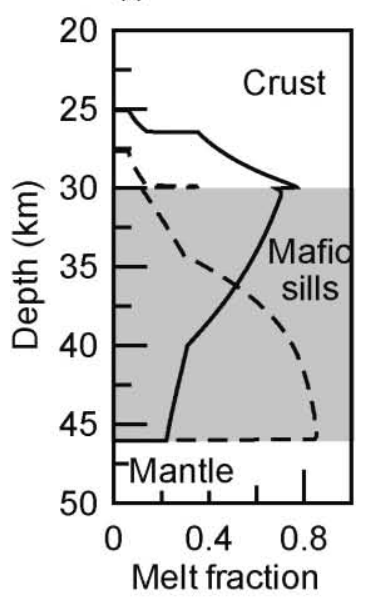

Figure 3 Temperatures (a, c, e) and melt fractions (b, d, f) distribution in a crust that has been intruded by a total of $16 \mathrm{~km}$ of mafic sills. The mafic magma is injected at $1285^{\circ} \mathrm{C}$ and contains $2.5 \mathrm{wt} \%$ $\mathrm{H}_{2} \mathrm{O}$. (a, b) The mafic magma emplacement rate is $2 \mathrm{~mm} / \mathrm{yr}$ and mafic magma has been injected over $8 \mathrm{My}$. (c, d) The mafic magma emplacement rate is $5 \mathrm{~mm} / \mathrm{yr}$ and mafic magma has been injected over $3 \cdot 2 \mathrm{My}$. (e, f) The mafic magma emplacement rate is $10 \mathrm{~mm} / \mathrm{yr}$ and mafic magma has been injected over $1.6 \mathrm{My}$. The crust is pelitic. The continuous line is for overaccretion; the dashed line is for underaccretion.

generation of the partial melt is controlled by the diffusion of heat, transferred from the mafic magma through the crust. The heat transfer from the mafic magma is balanced by the heat lost by conduction through the crust towards Earth's surface. The rate of crustal melt generation starts rapidly and corresponds to a rapid increase in the melting degree close to the 
(a) Crust is mafic granulite

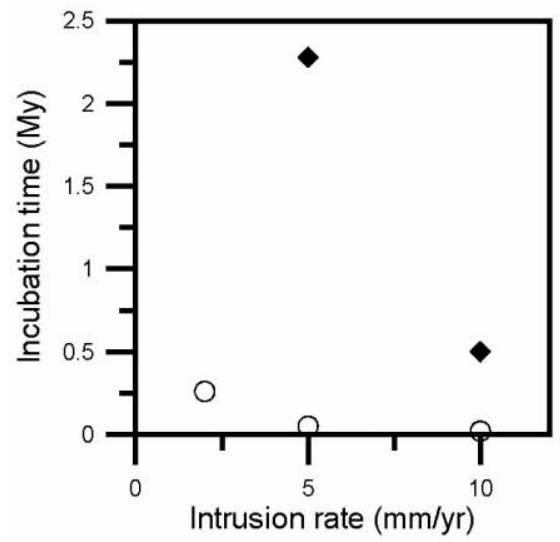

(b) Crust is amphibolite



(c) Crust is pelite

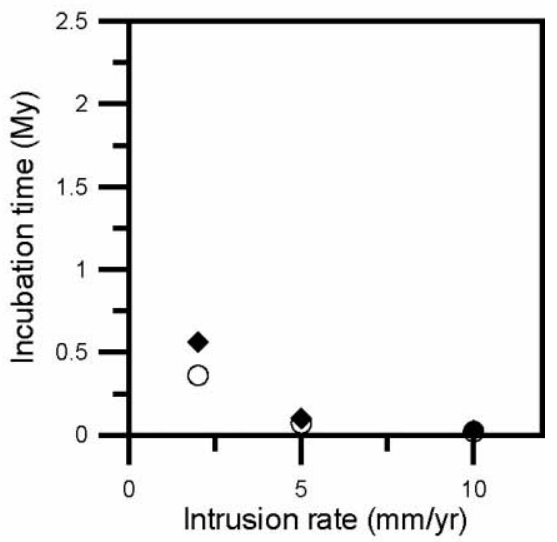

Residual melt

Partial melt

Figure 4 Incubation times between the injection of the first mafic sill and production of the first residual and partial melts for different mafic magma intrusion rates and an emplacement geometry by overaccretion. The mafic magma is injected at $1285^{\circ} \mathrm{C}$ and contains $2.5 \mathrm{wt} \% \mathrm{H}_{2} \mathrm{O}$ : (a) The crust is mafic granulite; (b) The crust is an amphibolite; (c) The crust is a pelite. For a mafic granulite crust no partial melting was obtained with an intrusion rate of $2 \mathrm{~mm} / \mathrm{yr}$.

(a) Crust is mafic granulite

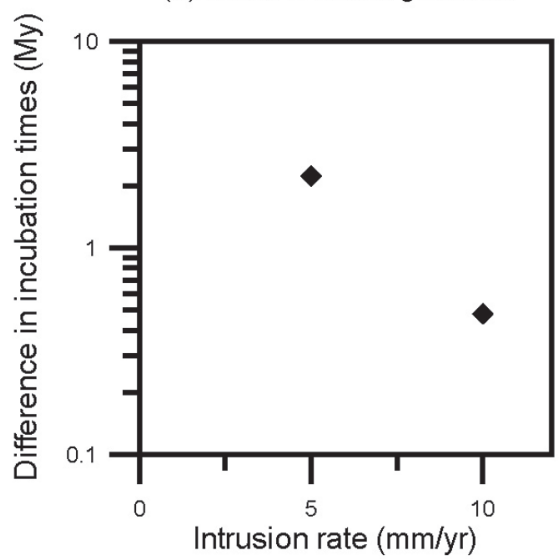

(b) Crust is amphibolite
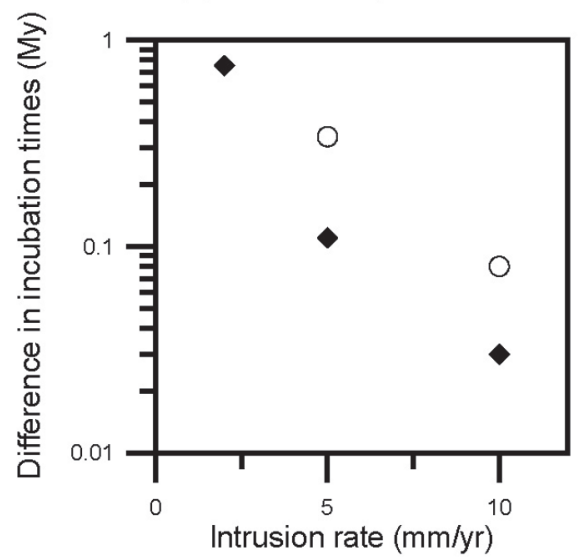

(c) Crust is pelite

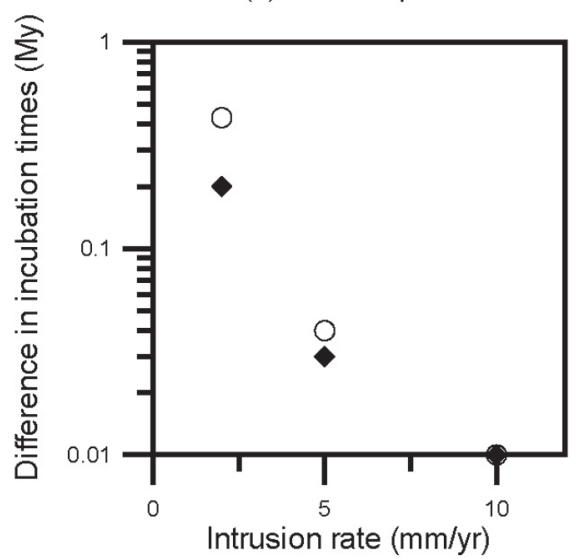

- Overaccretion

Underaccretion

Figure 5 Differences between the incubation times for the partial melts and the incubation times for the residual melt, for different mafic magma intrusion rates and emplacement geometries: (a) The crust is mafic granulite; (b) The crust is an amphibolite; (c) The crust is a pelite. The mafic magma is injected at $1285^{\circ} \mathrm{C}$ and contains $2.5 \mathrm{wt} \%$ $\mathrm{H}_{2} \mathrm{O}$. In the case of underaccretion, after the emplacement of $16 \mathrm{~km}$ of mafic magma, no partial melting of the crust occurs for a mafic granulite crust at any of the tested emplacement rate, and for an ampholitic crust with an emplacement rate of $2 \mathrm{~mm} / \mathrm{yr}$.

contact with the mafic magma. The rate of crustal melt generation then slows down because further increase in melt volume requires an increase in thickness of the partially molten crust, and this thickness increase is limited by heat diffusivity. The rate of partial melt generation is less sensitive to the mafic magma emplacement rate than the rate of residual melt generation. These differences in melt generation mechanisms explain the evolution of the ratios of partial melt over residual melts (Fig. 6). The residual melt is generated first as it has a lower solidus temperature and consequently a shorter incubation time (Fig. 4). After the incubation time for partial melt is reached, the volume of partial met increases rapidly, resulting in a peak in the curve of partial melt over residual melt. The value of the ratio at the peak depends on the fertility of the crust and on the emplacement rate. In most cases, it is below 1, i.e. the quantity of residual melt is always greater than the quantity of partial melt. For a very fertile crust and a fast emplacement rate, the peak can be $>1$ and the amount of partial melt is dominant. However, after a time, which depends on the mafic magma emplacement rate, the residual melt always comes to dominate over the partial melt because its volume increases with each new mafic magma injection more rapidly than the volume of crustal rock that is partially melted.

\subsection{Mafic magma emplacement by underaccretion}

In the case of mafic magma emplacement by underaccretion, the level of magma injection becomes deeper with time and moves away from the mafic magma-crust boundary. The maximum in the thermal anomaly develops at the bottom of the mafic magma column. As a consequence, the partial melting of the crust is more limited than in the case of overaccretion (Fig. 3). No partial melting of the crust is 
(a) Crust is mafic granulite

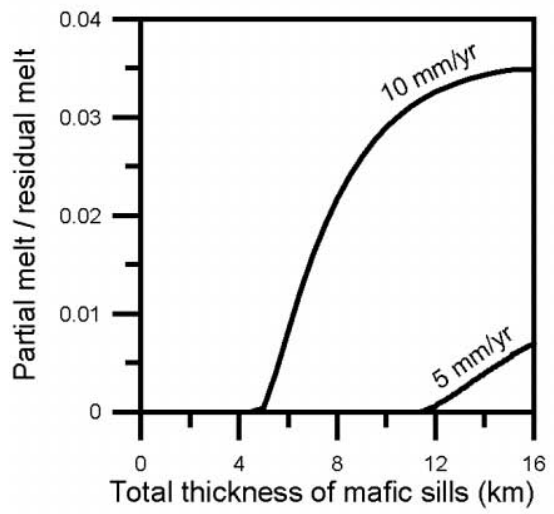

(b) Crust is amphibolite

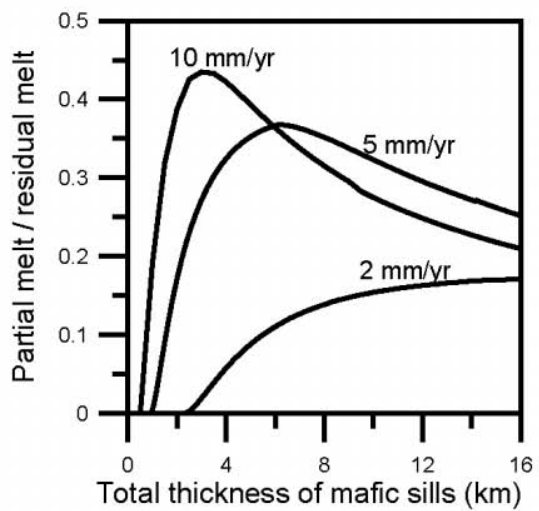

(c) Crust is pelite

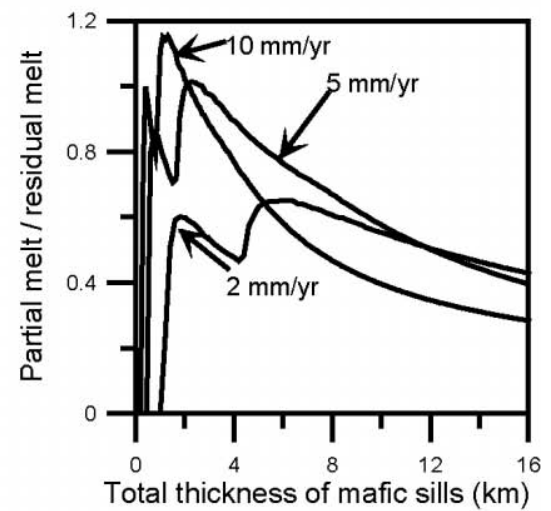

Figure 6 Ratio of the thickness of accumulated melts generated by crust partial melting over the thickness of accumulated melts residual from mafic magma crystallisation for mafic magma intrusion rates of 2 , 5 and $10 \mathrm{~mm} / \mathrm{yr}$ and a mafic magma emplacement by overaccretion. The mafic magma is injected at $1285^{\circ} \mathrm{C}$ and contains $2.5 \mathrm{wt} \% \mathrm{H}_{2} \mathrm{O}$. In abscissa is the total thickness of emplaced mafic magma. (a) The crust is mafic granulite (b) The crust is an amphibolite; (c) The crust is a pelite. Note the change in scale of partial melt/residual axis from mafic granulite to amphibolite to pelite.

(a) Crust is amphibolite



(b) Crust is pelite



Figure 7 Ratio of the thickness of accumulated melts generated by crust partial melting over the thickness of accumulated melts residual from mafic magma crystallisation for different emplacement rates and a mafic magma emplacement by underaccretion. The mafic magma is injected at $1285^{\circ} \mathrm{C}$ and contains $2.5 \mathrm{wt} \% \mathrm{H}_{2} \mathrm{O}$. (a) The crust is an amphibolite; (b) The crust is a pelite. This ratio is very low in the case of an amphibolitic crust and emplacement rate of 5 and $10 \mathrm{~mm} / \mathrm{yr}$. For an emplacement rate of $2 \mathrm{~mm} / \mathrm{yr}$, there is no melting of an amphibolitic crust. No partial melting of a mafic granulite crust is achieved for any of the emplacement rates.

achieved for a refractory granulitic crust. Due to the deeper level of the temperature anomaly compared to the overaccretion case, the melting degree in the mafic magma is higher and more residual melt is produced (Fig. 3). The incubation times for the generation of the residual melt by underaccretion and by overaccretion are similar. The incubation time for partial melting is longer for underaccretion, especially at low emplacement rates (Fig. 5). Due to the low temperatures at the mafic magma-crust boundary, the melting degree of an amphibolitic crust is very low (less than $4 \%$ for an emplacement rate of $10 \mathrm{~mm} / \mathrm{yr}$ ) and the quantity of melt produced represents less than $10 \%$ of the total melt (Fig. 7). More partial melt is generated from a pelitic crust, but still significantly less than in the case of overaccretion (Figs 6, 7). With an emplacement rate of $2 \mathrm{~mm} / \mathrm{yr}$, the amphibolitic crust does not melt during $8 \mathrm{Myr}$ of mafic injection.

\subsection{Random emplacement of mafic magma}

For random emplacement of the mafic sills, each sill emplacement depth is selected randomly between the Moho and an upper limit in the lower crust according to a continuous uniform distribution law. Screens of crust become sandwiched between sills. The model is run with an emplacement upper limit of $29.5 \mathrm{~km}, 25 \mathrm{~km}$, and $20 \mathrm{~km}$, in order to test the influence of sill scattering on melt production. In all cases, the lower limit was the Moho, which is initially set at $30 \mathrm{~km}$ depth and then displaced downwards with each intrusion. If the emplacement upper limit is far from the initial Moho (upper limit is $20 \mathrm{~km}$ ), the sills dispersion is high and many lower crust screens will be sandwiched by sills. In contrast, if the upper limit is close to the initial Moho (upper limit is $29 \cdot 5 \mathrm{~km}$ ), the sill dispersion is low and sills mostly intrude previously emplaced mafic intrusions (Fig. 8).

The incubation times for residual melt and for partial melt generation are longer than in the case of mafic magma emplacement at a fixed depth, because the heat advection by the magma is less focused and the resulting thermal anomaly is broader and situated at higher levels in the crust (Fig. 8). The duration of the incubation period increases with sill dispersion (Fig. 9). After the mafic magma solidus is exceeded, less melt is produced by mafic magma crystallisation than in the case of a fixed depth of mafic magma emplacement, because of the lower temperatures. For a mafic granulite crust, partial melting is not achieved if the mafic magma emplacement rates are less than $10 \mathrm{~mm} / \mathrm{yr}$. With sills scattered in the lower crust, partial melting is enhanced by the sandwiching of crustal screens that 
(a)

\section{Temperature $\left({ }^{\circ} \mathrm{C}\right)$} $400 \quad 800 \quad 1200$

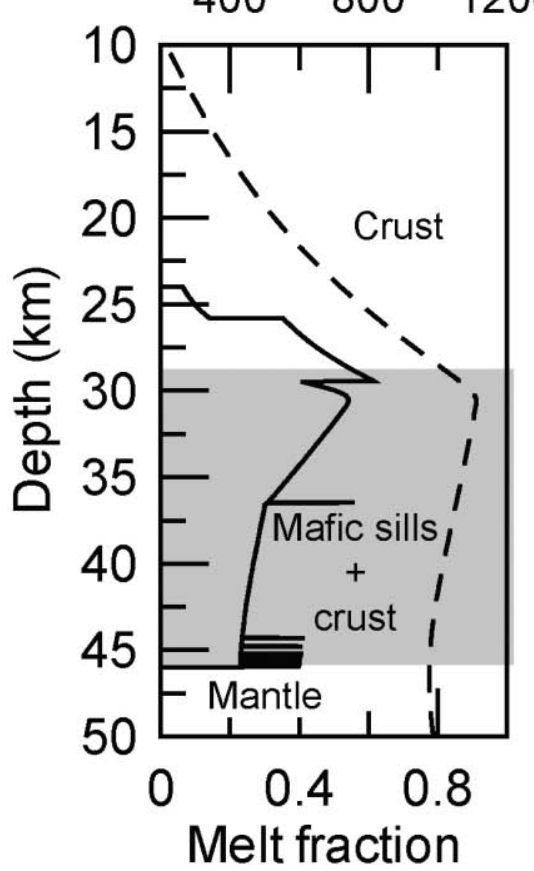

(b)

Temperature $\left({ }^{\circ} \mathrm{C}\right)$ $400 \quad 800 \quad 1200$

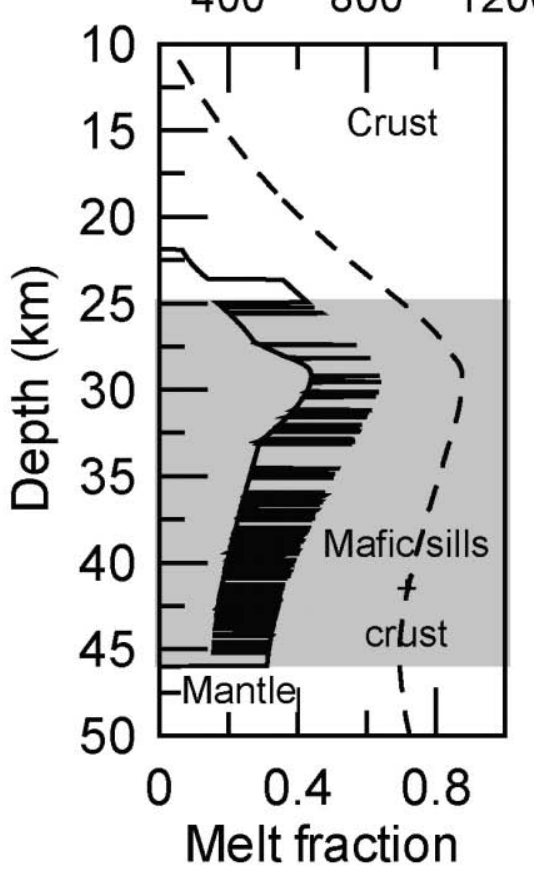

(c) Temperature $\left({ }^{\circ} \mathrm{C}\right)$

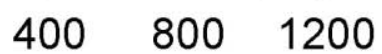



Figure 8 Temperatures (dashed lines) and melt fractions (continuous lines) distribution in a crust that has been intruded by a total of $16 \mathrm{~km}$ of mafic sills with an emplacement rate of $5 \mathrm{~mm} / \mathrm{yr}$. The mafic magma is injected at $1285^{\circ} \mathrm{C}$ and contains $2.5 \mathrm{wt} \% \mathrm{H}_{2} \mathrm{O}$. The crust is pelitic. The sills are randomly emplaced between (a) $29 \cdot 5 \mathrm{~km}$ and the Moho; (b) $25 \mathrm{~km}$ and the Moho; (c) $20 \mathrm{~km}$ and the Moho. The initial Moho is at $30 \mathrm{~km}$ and moves downwards with each sill intrusion. The spikes in the melt fractions curves correspond to screens of crust sandwiched by the sills.

(a) Residual melt

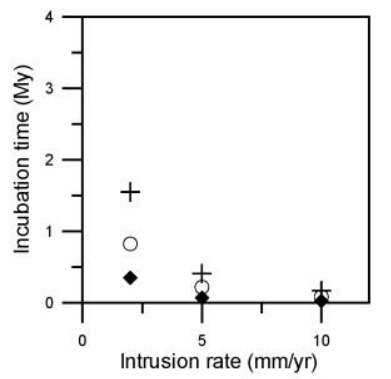

(c) Partial melt : crust is amphibolite

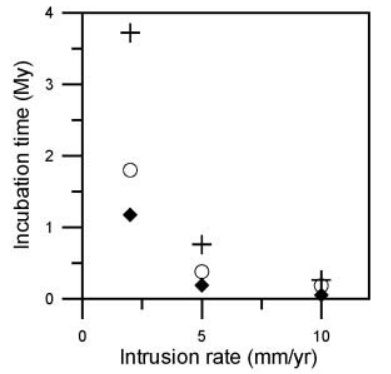

0
+ (b) Partial melt : crust is mafic granulite

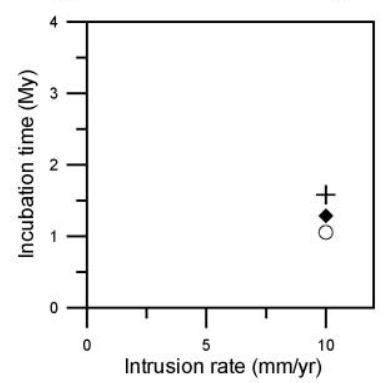

(d) Partial melt : crust is pelite

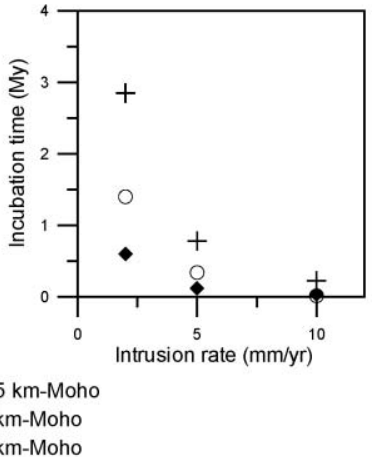

Figure 9 Incubation times between the injection of the first mafic sill and production of the first residual (a) and partial melts for a mafic granulite (b) an amphibole (c) and a pelite crust (d), for different mafic magma intrusion rates. The mafic magma is injected at $1285^{\circ} \mathrm{C}$ and contains $2.5 \mathrm{wt} \% \mathrm{H}_{2} \mathrm{O}$. Results are given for sills randomly emplaced between $29.5 \mathrm{~km}$ and the Moho, $25 \mathrm{~km}$ and the Moho, and $20 \mathrm{~km}$ and the Moho. In abscise is the total thickness of emplaced mafic magma. For a mafic granulite crust partial melting is achieved only at an emplacement rate of $10 \mathrm{~mm} / \mathrm{yr}$. are heated from both their upper and lower sides by mafic magma. However, this process is counterbalanced by lower temperatures, due to less focused heat advection. Thus the amount of partial melt is comparable to that produced by overaccretion. The production of residual melt is more limited, and thus the ratio of partial melt to residual melt exhibits a high peak shortly after the crustal solidus is exceeded (Figs 10, 11). However, the intimate interstratification of regions of partial melt and residual melt makes it more likely that hybrid magmas can be segregated.

For a pelitic upper crust, this ratio reaches 10, in the case of an upper limit of sill emplacement at $20 \mathrm{~km}$, and is higher for higher emplacement rates (Fig. 11). The dominance of partial melt over residual melt lasts several million years and is more pronounced with highly scattered sills. After $16 \mathrm{~km}$ of mafic magma have been randomly emplaced in the whole lower crust (from $20 \mathrm{~km}$ depth to Moho) with an intrusion rate of $5 \mathrm{~mm} /$ $\mathrm{yr}$, the ratio of partial melt over residual melt is still 0.76 (Fig. 11b), almost twice as much as in the case of a fixed emplacement depth (Fig. 6b). For an amphibolitic crust, the residual melt stays dominant relative to the partial melt for the duration of the simulation (Figs 10a, 11a). For a mafic granulite, the partial melting with a mafic magma emplacement rate of $10 \mathrm{~mm} / \mathrm{yr}$ produces a thickness of partial melt of less than $50 \mathrm{~m}$ resulting in extremely low ratios of partial melt to residual melts (less than $10^{-2}$ ).

\subsection{Dry and hot mafic magma}

The model was also run with a primitive mafic magma emplaced at $1346^{\circ} \mathrm{C}$ and containing only $0.3 \mathrm{wt} \% \mathrm{H}_{2} \mathrm{O}$. The mafic magma has the same solidus as the mafic magmas richer in $\mathrm{H}_{2} \mathrm{O}$ because of the concentration of the $\mathrm{H}_{2} \mathrm{O}$ in the residual melt, but its fertility is significantly lower (Fig. 2). Because the 
(a) Crust is amphibolite

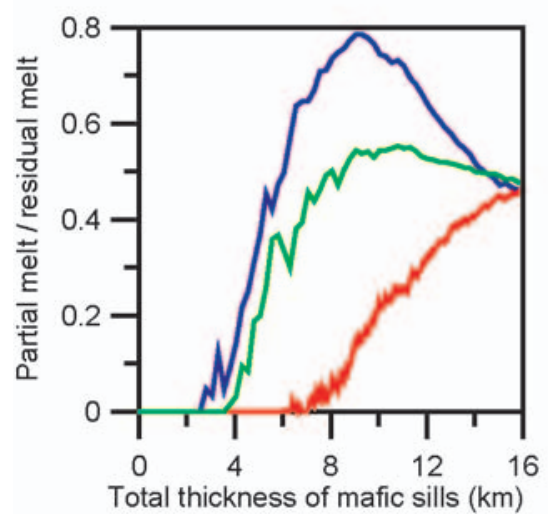

(b) Crust is pelite

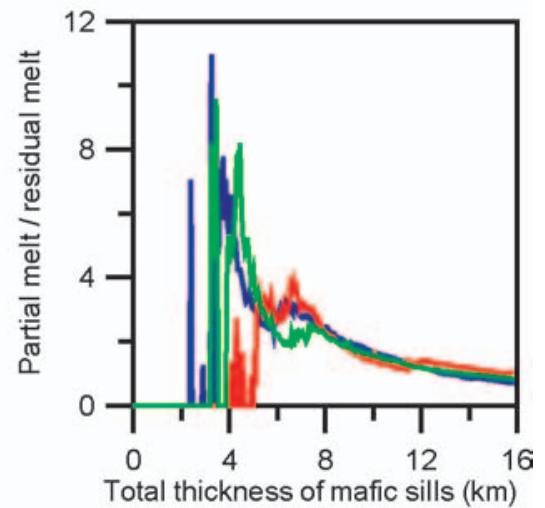

Total thickness of mafic sills $(\mathrm{km})$

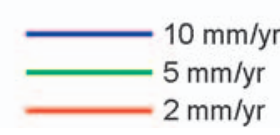

Figure 10 Ratio of the thickness of accumulated melts generated by crust partial melting over the thickness of accumulated melts residual from mafic magma crystallisation for mafic sills randomly emplaced between $20 \mathrm{~km}$ and the Moho, at emplacement rates of 2, 5, and $10 \mathrm{~mm} / \mathrm{yr}$. The mafic magma is injected at $1285^{\circ} \mathrm{C}$ and contains $2.5 \mathrm{wt} \% \mathrm{H}_{2} \mathrm{O}$. (a) The crust is an amphibolite; (b) The crust is a pelite.

(a) Crust is amphibolite

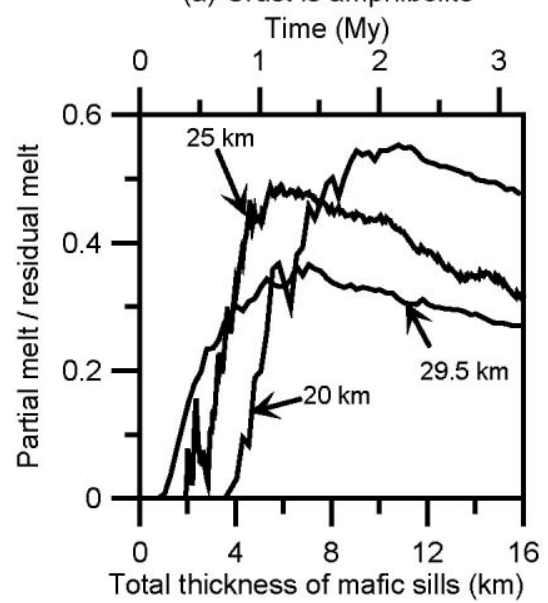

(b) Crust is pelite Time (My)

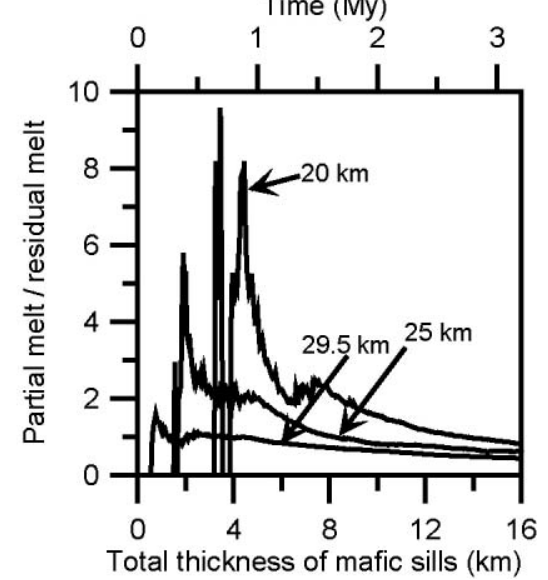

Figure 11 Ratio of the thickness of accumulated melts generated by crust partial melting over the thickness of accumulated melts residual from mafic magma crystallisation for mafic sills randomly emplaced between $29 \cdot 5 \mathrm{~km}$ and the Moho, $25 \mathrm{~km}$ and the Moho, and $20 \mathrm{~km}$ and the Moho, at an emplacement rates of $5 \mathrm{~mm} / \mathrm{yr}$. The mafic magma is injected at $1285^{\circ} \mathrm{C}$ and contains $2.5 \mathrm{wt} \% \mathrm{H}_{2} \mathrm{O}$. (a) The crust is an amphibolite; (b) The crust is a pelite.

Table 1 Incubation periods in My between the emplacement of the first sill and the accumulation of melts for different emplacement geometries in the case of a basalt with $0.3 \mathrm{wt} \% \mathrm{H}_{2} \mathrm{O}$ injected at $1346^{\circ} \mathrm{C}$ at a rate of $5 \mathrm{~mm} / \mathrm{yr}$

\begin{tabular}{lccccc}
\hline & Overaccretion & Underaccretion & $\begin{array}{c}\text { Random } \\
29 \cdot 5 \mathrm{~km}-\text { Moho }\end{array}$ & $\begin{array}{c}\text { Random } \\
\text { 25 km-Moho }\end{array}$ & $\begin{array}{c}\text { Random } \\
\text { 20 km-Moho }\end{array}$ \\
\hline Residual & $0 \cdot 06$ & $0 \cdot 05$ & $0 \cdot 06$ & $0 \cdot 22$ & $0 \cdot 42$ \\
Crustal: Pelite & $0 \cdot 09$ & $0 \cdot 1$ & $0 \cdot 1$ & $0 \cdot 33$ & $0 \cdot 61$ \\
Crustal: Amphibolite & $0 \cdot 16$ & $0 \cdot 25$ & $0 \cdot 16$ & $0 \cdot 41$ & 0.68 \\
Crustal: Granulite & 1.53 & $>3 \cdot 2$ & $1 \cdot 93$ & $2 \cdot 12$ & $2 \cdot 85$ \\
\hline
\end{tabular}

mafic magma is emplaced at high temperature, the incubation periods are slightly shorter in comparison with models involving cooler magmas (Table 1). The main effects of emplacing hot mafic magma are that significantly less residual melt is produced because of the lower melt fractions in the mafic magma at any given temperature, and more crust partial melting is predicted because more heat is transferred to the crust. Higher ratios of partial melt to residual melt are predicted (Figs 12, 13). Even with an amphibolitic crust the partial melt can dominate over the residual melt if the mafic magma is emplaced randomly or by overaccretion (Figs 12b, 13b). For a pelitic crust, the peak in the ratio of partial melt to residual melt exceeds 10 in case of overaccretion and 100 for random emplacement (Figs 12c, 13c). However, for a mafic granulite crust, the production of partial melt is very limited and the residual melt dominates (Figs 12a, 13a). 
(a) Crust is mafic granulite

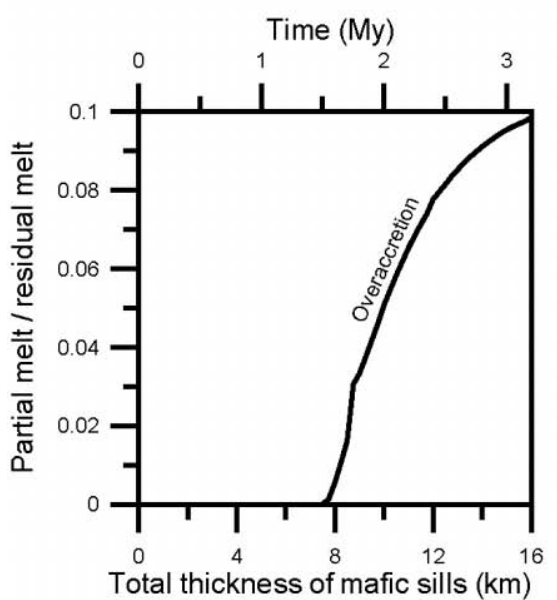

(b) Crust is amphibolite

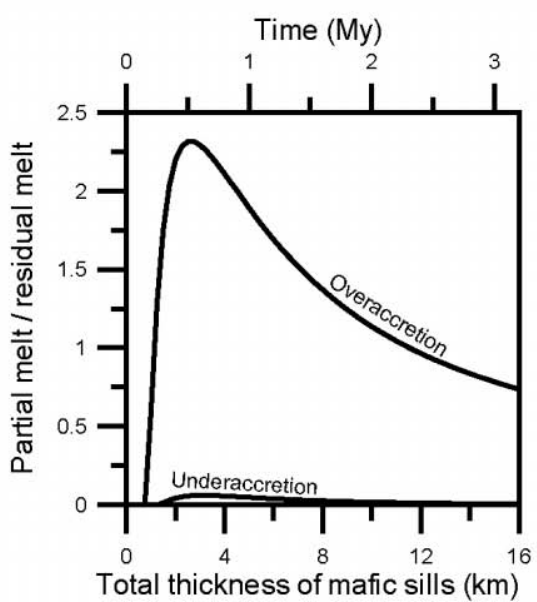

(c) Crust is pelite



Figure 12 Ratio of the thickness of accumulated melts generated by crust partial melting over the thickness of accumulated melts residual from mafic magma crystallisation for mafic magma emplacement by overaccretion and underaccretion at a rate of $5 \mathrm{~mm} / \mathrm{yr}$. The mafic magma is injected at $1346^{\circ} \mathrm{C}$ and contains $0 \cdot 3 \mathrm{wt} \% \mathrm{H}_{2} \mathrm{O}$. (a) The crust is a dry mafic granulite; (b) The crust is an amphibolite; (c) The crust is a pelite. For an emplacement by underaccretion, there is no melting of a mafic granulite crust.

(a) Crust is mafic granulite

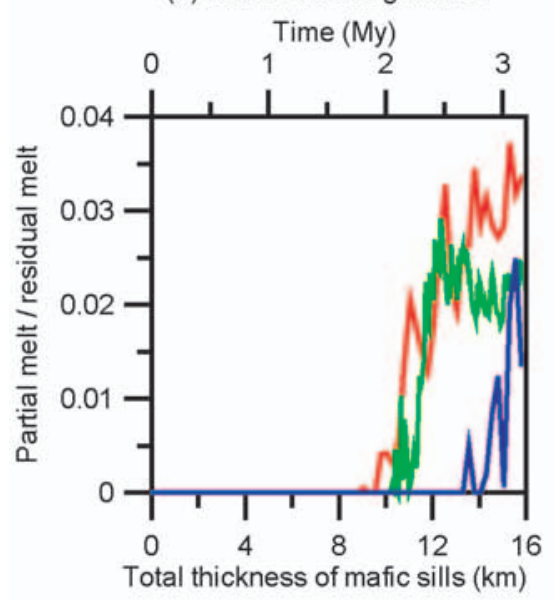

(b) Crust is amphibolite

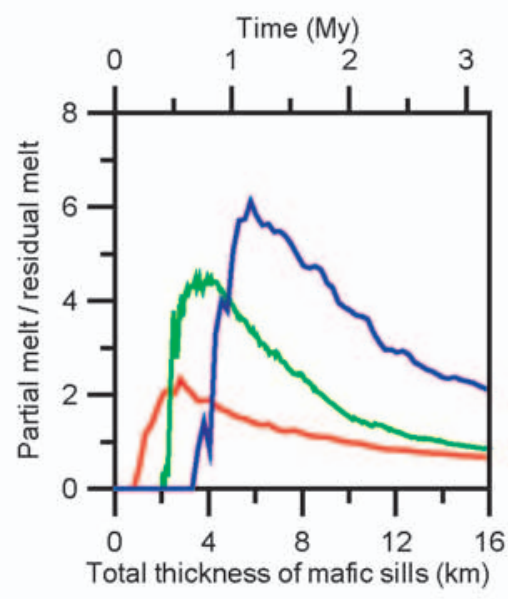

(c) Crust is pelite

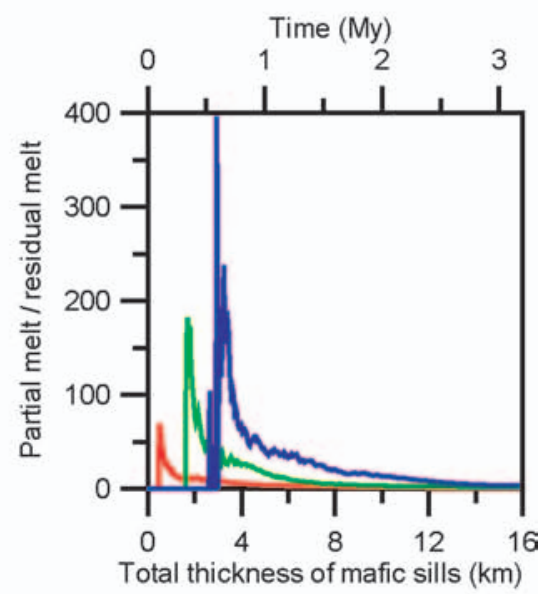

$29.5 \mathrm{~km}-$ Moho

$25 \mathrm{~km}-$ Moho

$20 \mathrm{~km}-$ Moho

Figure 13 Ratio of the thickness of accumulated melts generated by crust partial melting over the thickness of accumulated melts residual from mafic magma crystallisation for mafic sills randomly emplaced between $29 \cdot 5 \mathrm{~km}$ and the Moho, $25 \mathrm{~km}$ and the Moho, and $20 \mathrm{~km}$ and the Moho, at an emplacement rate of $5 \mathrm{~mm} / \mathrm{yr}$. The mafic magma is injected at $1346^{\circ} \mathrm{C}$ and contains $0.3 \mathrm{wt} \% \mathrm{H}_{2} \mathrm{O}$. (a) The crust is a dry mafic granulite. (b) The crust is an amphibolite; (c) The crust is a pelite.

\section{Discussion}

\subsection{The contribution of crust partial melting}

Heat transfer calculations show that the partial melting of the crust with mafic magma as a heat source implies the simultaneous generation of silicic residual melt by crystallisation of the mafic magma. The proportions of residual and partial melts strongly depends on the respective fertility of the mafic magma and crust, on the mafic magma emplacement rate and on its emplacement geometry. Since the incubation period for the residual melt is shorter than for partial melt, the first melts to be generated are residual from the mafic magma and would carry a mantle signature, assuming that mantle and crust isotope signatures are discernable. The Adamello batholith, Italy, provides an example in which geochemical and isotopic data indicate that the oldest rocks were generated by basalt fractional crystallisation and younger granites exhibit an increasing crustal component (Kagami et al. 1991). The duration of the period of pure residual melt is limited if the crust is fertile and if the mafic magma emplacement rate is high. After the solidus of the crust has been exceeded there is a peak in the ratio of partial melt to residual melt. If the mafic magma is cool and wet, this peak is transient and the residual melt always dominates in the long term. If the mafic magma is dry and hot, and if the crust is fertile enough (e.g. amphibolitic or pelitic crust), the amount of partial melt can be one to two orders of magnitude higher than the amount of residual melt. In this case, the partial melt can remain dominant for protracted periods. However, the present results indicate that the partial melting of a refractory mafic granulitic crust cannot provide significant quantities of melt without being accompanied by voluminously more abundant production of residual 
melt, even when the crust is intruded by a high-temperature magma. This result implies that models of A-type granite generation that involve the remelting of an already meltdepleted protolith must allow for a sufficiently fertile crust to be realistic, i.e. a crust that still retains some hydrous minerals (Clemens et al. 1986; Collins et al. 1982).

\subsection{Emplacement of mafic magma in a fertile metasedimentary crust: Implications for the generation of S-type granites}

S-type granites are believed to be generated by the melting of a metasedimentary protolith, although, on the basis of experimental data, Patiño Douce (1999) argues that only peraluminous leucogranites are pure crustal melts and that other S-type granites originate by mixing of basalts and crustal melts. According to the present results, one way to produce a very high proportion of crustal melt and generate S-type granites is to scatter mafic sills in a fertile crust. In this particular case the intense melting of the crust can produce ten times more partial melt than mafic magma residual melts. If the mafic magma is hot and dry, this proportion is even higher. The pelitic crust that is used to model a fertile metasedimentary crust is an end-member in terms of fertility and many S-type granite may be derived from a less fertile metagreywacke protolith (Clemens \& Wall 1981). Even in the case of a slightly less fertile source rock, abundant crustal melts would be produced if the mafic magma is hot and dry and is randomly distributed in the crust.

In the Lachlan Fold Belt, Australia, the S-type granites are generally older than the I-type granites occurring in the same batholith (Chappell \& White 2001), although in some parts of the belt the S-type granites have the same age or are younger of than the I-type granites. This is consistent with a model of scattered sills, where a high peak of partial melt is generated shortly after the end of the incubation period, with a possible enhancing of the peak and reduction of the incubation period due to fluid flux melting. With time, the residual melts become dominant, which would translate in the field by the appearance of I-type granite. However, the random character of the sills emplacement results in highly irregular trends of residual and partial melt generation. Thus depending on the possible fluctuations in the intrusions rates and on the way the sills are scattered in the crust, varying age relationships between S-types and I-type granites are expected.

\subsection{Emplacement of mafic magma in an amphibolitic crust: implications for the generation of I-type granites} The partial melting of an amphibolitic lower crust is a popular paradigm for the generation of I-type granite (e.g. Chappell \& White 1984; Coleman et al. 1995; Petford \& Atherton 1996; Topuz et al. 2005), although Roberts \& Clemens (1993) argued that normal and high-K calc-alkaline melts could not be produced by the melting of a basaltic amphibolites and that the most suitable source for I-type melts are calc-alkaline and high-K calc-alkaline andesites and basaltic andesites. However, recent experimental work by Sisson et al. (2005) predicts that common granitic and rhyolitic melt can form by advanced crystallisation-differentiation or by low-degree partial melting of medium to high-K basalts. The present models indicate that, in an arc context, where the mafic magma is relatively cool and wet, the production of partial melt of amphibolite is subordinate to the production of melt by crystallisation of the wet mafic magma. Moreover, as the residual melt is richer in $\mathrm{H}_{2} \mathrm{O}$ than the partial melt, it is less viscous, less dense and easier to extract. The partial melt derived from an amphibolitic lower crust can be dominant only if the mafic magma is dry and hot.
Thus the present model predicts that the melt produced by emplacement of wet arc-type mafic magma in contact with an amphibolitic lower crust would carry a mantle signature, but possibly with some crustal contamination, depending on the geometry of sill emplacement and whether the amphibolite is old enough to have evolved a distinctive radiogenic isotope signature. The expected geochemical characteristics are observed, for example, in the Sierra Nevada (Coleman et al. 1992, 1995), in the central Andes (Lucassen et al. 2004) and in the Eastern Pontides granodiorites (Topuz et al. 2005).

\subsection{Emplacement of mafic magma in a refractory crust: implications for the generation of A-type granites}

Many models have been proposed for the generation of A-type granite, which include differentiation from mafic to intermediate magma (Bonin 2004; Foland \& Allen 1991; Kerr \& Fryer 1993; Turner \& Foden 1996; Turner et al. 1992) and lowpressure melting of calc-alkaline rocks (Patiño Douce 1997, 1999). One model involves the partial melting of an already melt-depleted granulitic crust (Collins et al. 1982). The mafic granulitic crust that is used in the present simulation is an end member and is particularly refractory. With such a refractory crust, even in the most favourable conditions for crustal melting, i.e. hot mafic magmas and randomly emplaced sills, only insignificant quantities of partial melt can be produced.

According to Clemens et al. (1986), A-type granite can originate from a source that contains residual biotite and that produces very small amounts of melts. This type of crust is less refractory than the mafic granulite that is used in the present models, but the production of the crustal melt would still be associated with the production of significantly larger amounts of melt residual from the mafic magma. Another model is the partial melting of calc-alkaline rocks at shallow depth (Patiño Douce 1997, 1999). A calc-alkaline rock would be more fertile than a granulitic rock, however at shallow depth initial temperatures are low and heat is lost rapidly because of the proximity of the Earth cold surface. Thus very large amounts of mafic magma are required to heat the crust at shallow depth (Annen et al. 2006; Annen \& Sparks 2002).

Because of the large quantities of mafic magma required to melt either a granulite crust or a calc-alkaline rock at shallow depth, the production of an A-type granite that is mostly of crustal origin would require a selective segregation and extraction of the crustal melt. If screens of partially melted crust are sandwiched between sills containing residual melt, mixing of the two melts seems unavoidable and the crustal melts would merely represent a minor contamination of the largely dominant mantle melt. Further studies are needed to determine if selective extraction is feasible in the case of over-accreting sills, where the partially melted crust overlays the mafic magma.

\subsection{Melt diversity}

The diversity of granites can reflect the diversity of the protoliths. Moreover, in a deep hot zone a complex system builds up and a diversity of melt is generated because of the coexistence of crustal melts and mantle melts and because the melting degree of the crust and mafic magma varies both in space and time. The temperature distribution in the deep hot zone and thus the melting degree depends on the intrusion emplacement geometry (Fig. 3) and evolves with time depending on the mafic magma intrusion rate.

With the present numerical simulations the proportions of residual melts and partial melts generated at the source level are estimated, but Jackson et al. (2003) showed that petrologic diversity is also acquired during melt segregation. If buoyancydriven, the melt segregation rates are controlled by the viscosity and the melting degree. Both parameters are highly 
variable in the deep hot zone, although the viscosity of the residual melt is lower than the viscosity of the crustal melt because of the concentration of $\mathrm{H}_{2} \mathrm{O}$ in the residual melt. The viscosities were estimated to $10^{2}-10^{4} \mathrm{~Pa}$ for the residual melt and to higher values $\left(10^{5}\right.$ up to $\left.10^{12} \mathrm{~Pa} \mathrm{~s}\right)$ for the partial melt (Annen et al. 2006). Thus the actual proportion of the different melts at the granite final emplacement level might not exactly reflect the proportions of melts at the source because of differential segregation. More complexity is added to the system if the magma successively stalls at different levels in the crust (Bonin 2007).

\subsection{Flux melting}

In the present modelling, $\mathrm{H}_{2} \mathrm{O}$ flux is not simulated. The $\mathrm{H}_{2} \mathrm{O}$ exsolved by mafic magma crystallisation is assumed to remain in the solidified mafic magma, and the solidus for mafic magma remelting is similar to the $\mathrm{H}_{2} \mathrm{O}$-saturated solidus for mafic magma crystallisation. In nature, the free $\mathrm{H}_{2} \mathrm{O}$ may escape the mafic magma and flux the overlying rocks, favouring fluidpresent partial melting of the crust. In addition the loss of $\mathrm{H}_{2} \mathrm{O}$ from the mafic intrusions would make them difficult to remelt. These effects would result in a shorter incubation time for the partial melt and an increase in the ratio of partial melt over residual melt. However, these effects would be noticeable only when a significant part of the mafic magma crystallises enough for the residual melt to become saturated in $\mathrm{H}_{2} \mathrm{O}$, i.e. at the beginning of the hot zone formation, when the crust is still cold. In the case of low emplacement rates, and in the case of sills with random emplacement we would expect a higher peak of partial melt to residual melt. On the long term, however, when the hot zone is mature and the mafic magma equilibrates at higher temperature, no more $\mathrm{H}_{2} \mathrm{O}$ would be released by the mafic magma and the residual melt would become dominant.

\subsection{The intruded mafic rocks}

According to the present thermal modelling, the generation of large volumes of differentiated melt to supply batholiths in Deep Hot Zones, involves the accumulation of kilometric thicknesses of mafic rocks. In the model presented the emplacement of $16 \mathrm{~km}$ of mafic magma at the Moho or scattered in the lower crust has been modelled. This amount of mafic magma is consistent with observations. For example, in Sierra Nevada, the thermobarometric study of xenoliths brought to the surface by volcanic activity indicates the existence, in the Miocene, of as much as $35 \mathrm{~km}$ of garnet pyroxenite forming the roots of the batholith. This garnet pyroxenite is interpreted to be the restites or cumulates left over by the granitoid generation (Ducea 2002). The present results strongly suggest that most of these rocks must be cumulates produced by mafic magma differentiation rather than restites issued from melting of an amphibolitic crust. Ducea (2002) noted that the pyroxenite cumulates would be seismologically interpreted as mantle. The present depth of the Moho in the Sierra Nevada has been estimated at 30 to $40 \mathrm{~km}$ (Fliedner et al. 2000; Ruppert et al. 1998; Wernicke et al. 1996). At pressures over $10 \mathrm{kbar}$, the mafic and ultramafic cumulates are denser than the underlying mantle and prone to foundering (Ducea 2002; Jull \& Kelemen 2001). The foundering of the roots of the Sierra Nevada into the mantle has been seismically imaged (Zandt et al. 2004). The Aleutian volcanic arc provides another example where ultramafic rocks interpreted as cumulates have been seismically identified at the base of the lower crust (Fliedner \& Klemperer 2000). An arc lower crust that has been thickened by magmatic underplating is exposed in the Kohistan complex (Yoshino \& Okudaira 2004; Yoshino et al. 1998).

\subsection{Sill emplacement geometry}

The emplacement geometry of the mafic magma intrusions strongly controls the ratio of partial melt to residual melt and the melt fractions. According to the models of Dufek \& Bergantz (2005), if intrusions are randomly orientated dykes instead of horizontal sills, the production of both residual and crustal melt is more limited. The intrusion of numerous randomly oriented dykes poses the problem of how to accommodate the volume of such a complex geometry. Layered rocks that are interpreted as mafic sills are seen on seismic profiles (Franke 1992; Fuchs et al. 1987; Wenzel \& Brun 1991). Laboratory experiments indicate that the level of sills emplacement is controlled by rigidity contrasts (Kavanagh et al. 2006). The development of a temperature anomaly and the presence of melt at the level of intrusion of the first emplaced sills might act as a rheological trap for the successive intrusions, inducing a feedback effect and the focusing of magma injection. In the case of shallow magmatic bodies, geochronological, geophysical and structural data suggest underaccretion is a common emplacement style (Benn et al. 1999; Bridgwater et al. 1974; Coleman et al. 2004; Cruden 1998; Cruden \& McCaffrey 2001; Harrison et al. 1999; Saint-Blanquat (de) et al. 2001). The sandwiching of crustal rock by sills is common. Septa of metasedimentary rocks crop out in the mafic complex of the Ivrea Zone (Quick et al. 1994). Quick et al. (1994) proposed a model for the formation of the Ivrea mafic complex where an active magma chamber is located at the top of the complex. This would roughly correspond to the present overaccretion model. Thus the three types of sill emplacement that have been modelled all seem to occur in nature, and further investigations are needed to understand how the emplacement geometry is controlled.

\section{Conclusions}

In Deep Hot Zones, melt can be simultaneously generated by incomplete crystallisation of intruded mafic magmas (mantle sources) and by partial melting of the crust (crustal sources). The contribution of each type of source depends on the geometry of the mafic magma emplacement, the fertility of the crust and the mafic magma emplacement rate. Numerical simulations of heat transfer show that the first melts are generated by mafic magma crystallisation, unless the solidus of the crust is lowered by flux of $\mathrm{H}_{2} \mathrm{O}$ released by mafic magma crystallisation. The ratio of partial melt to residual melt exhibits a peak after the solidus of the crust is exceeded. If the injected mafic magma is cool and wet, typical of arc contexts, the crustal partial melt is dominant only if the sills are randomly emplaced into a fertile crust. In the case of an amphibolitic crust, the contribution of crustal partial melting would be very limited and the crystallisation of the mafic magma is the main mechanism of silicic melt generation.

The emplacement of hot and dry mafic magma results in the generation large volumes of crustal melt if the crust is amphibolitic or pelitic. However, the partial melting of a granulitic protolith only produces very limited amount of crustal melt dominated by larger amount of melts residual from mafic magma crystallisation. Thus the generation of A-type granites by partial melting of a refractory crust would require the selective segregation and extraction of the A-type melt.

\section{Acknowledgements}

This paper greatly benefited from comments by Tony Kemp. Constructive reviews by John Clemens and an anonymous reviewer helped us to clarify the manuscript. CA was 
supported by a grant awarded by the Ernst and Lucie Schmidheiny Foundation. RSJS acknowledges a Royal Society Wolfson Merit Award. JDB acknowledges an NERC Senior Research Fellowship.

\section{References}

Annen, C., Blundy, J. D. \& Sparks, R. S. J. 2006. The Genesis of Calcalkaline Intermediate and Silicic Magmas in Deep Crustal Hot Zones. Journal of Petrology 47, 505-39. [Published online December 2005. doi:10.1093/petrology/egi084]

Annen, C. \& Sparks, R. S. J. 2002. Effects of repetitive emplacement of basaltic intrusions on thermal evolution and melt generation in the crust. Earth and Planetary Science Letters 203, 937-55.

Barbarin, B. 2005. Mafic magmatic enclaves and mafic rocks associated with some granitoids of the central Sierra Nevada batholith, California: nature, origin, and relations with the hosts. Lithos 80, 155-77.

Barboza, S. A. \& Bergantz, G. W. 1996. Dynamic model of dehydration melting motivated by a natural analogue: applications to the Ivra-Verbano zone. Transactions of the Royal Society of Edinburgh: Earth Sciences 87, 23-31.

Benn, K., Roest, W. R., Rochette, P., Evans, N. G. \& Pignotta, G. S. 1999. Geophysical and structural signatures of syntectonic batholith construction: the South Mountain Batholith, Meguma Terrane, Nova Scotia. Geophysical Journal International 136, 144-58.

Bergantz, W. 1989. Underplating and partial melting: Implications for melt generation and extraction. Science $\mathbf{2 4 5}, \mathbf{1 0 9 3 - 5}$

Blundy, J. D. \& Sparks, R. S. J. 1992. Petrogenesis of mafic inclusions in granitoids of the Adamello massif, Italy. Journal of Petrology 33, 1039-104.

Bonin, B. 2004. Do coeval mafic and felsic magmas in post-collisional to within-plate regimes necessarily imply two contrasting, mantle and crustal, sources? A review. Lithos 78, 1-24.

Bonin, B. 2007. A-type granites and related rocks: Evolution of a concept, problems and prospects. Lithos 97, 1-29.

Bridgwater, D., Sutton, J. \& Watterson, J. 1974. Crustal Downfolding Associated with Igneous Activity. Tectonophysics 21, 57-77.

Brown, M. 1994. The Generation, Segregation, Ascent and Emplacement of Granite Magma - the Migmatite-to-Crustally-DerivedGranite Connection in Thickened Orogens. Earth-Science Reviews 36, 83-130.

Chappell, B. W. \& White, J. R. 1984. I- and S-type granites in the Lachlan Fold Belt, southeastern Australia. In Xu, Keqin \& Tu, Guangchi (eds) Geology of granites and their metallogenic relations, 87-101. Beijing: Science Press.

Chappell, B. W. \& White, J. R. 2001. Two contrasting granite types: 25 years later. Australian Journal of Earth Sciences 48, 489-99.

Clemens, J. D., Holloway, J. R. \& White, A. J. R. 1986. Origin of an a-Type Granite - Experimental Constraints. American Mineralogist 71, 317-24.

Clemens, J. D. \& Mawer, C. K. 1992. Granitic Magma Transport by Fracture Propagation. Tectonophysics 204, 339-60.

Clemens, J. D. \& Vielzeuf, D. 1987. Constraints on melting and magma production in the crust. Earth and Planetary Science Letters 86, 287-306.

Clemens, J. D. \& Wall, W. J. 1981. Origin and crystallization of some peraluminous (S-type) granitic magmas. Canadian Mineralogist 19, $111-31$.

Coleman, D. S., Frost, T. P. \& Glazner, A. F. 1992. Evidence from the Lamarck Granodiorite for Rapid Late Cretaceous Crust Formation in California. Science 258, 1924-6.

Coleman, D. S., Glazner, A. F., Miller, J. S., Bradford, K. J., Frost, T. P., Joye, J. L. \& Bachl, C. A. 1995. Exposure of Late Cretaceous layered mafic-felsic magma system in the central Sierra Nevada batholith, California. Contribution to Mineralogy and Petrology 120, 129-36.

Coleman, D. S., Gray, W. \& Glazner, A. F. 2004. Rethinking the emplacement and evolution of zoned plutons: Geochronologic evidence for incremental assembly of the Tuolumne Intrusive Suite, California. Geology 32, 433-6.

Collins, W. J., Beams, S. D., White, A. J. R. \& Chappell, B. W. 1982. Nature and Origin of a-Type Granites with Particular Reference to Southeastern Australia. Contributions to Mineralogy and Petrology 80, 189-200.

Crisp, J. 1984. Rates of magma emplacement and volcanic output. Journal of Volcanology and Geothermal Research 20, 177-211.

Cruden, A. R. 1998. On the emplacement of tabular granites. Journal of the Geological Society 155, 853-62.
Cruden, A. R. \& McCaffrey, K. J. W. 2001. Growth of plutons by floor subsidence: Implications for rates of emplacement, intrusion spacing and melt-extraction mechanisms. Physics and Chemistry of the Earth Part A-Solid Earth and Geodesy 26, 303-15.

DePaolo, D. J. 1981a. A Neodymium and Strontium Isotopic Study of the Mesozoic Calc-Alkaline Granitic Batholiths of the SierraNevada and Peninsular Ranges, California. Journal of Geophysical Research 86, 470-88.

DePaolo, D. J. 1981b. Trace-Element and Isotopic Effects of Combined Wallrock Assimilation and Fractional Crystallization. Earth and Planetary Science Letters 53, 189-202.

Dimalanta, C., Taira, A., Yumul, G. P., Tokuyama, H. \& Mochizuki, K. 2002. New rates of western Pacific island arc magmatism from seismic and gravity data. Earth and Planetary Science Letters 202, $105-15$.

Domenick, M. A., Kistler, R. W., Dodge, F. C. W. \& Tatsumoto, M. 1983. Nd and Sr Isotopic Study of Crustal and Mantle Inclusions from the Sierra-Nevada and Implications for Batholith Petrogenesis. Geological Society of America Bulletin 94, 713-19.

Ducea, M. \& Saleeby, J. 1998. Crustal recycling beneath continental arcs: silica-rich glass inclusions in ultramafic xenoliths from the Sierra Nevada, California. Earth and Planetary Science Letters 156, 101-16.

Ducea, M. N. 2002. Constraints on the bulk composition and root foundering rates of continental arcs: A California arc perspective. Journal of Geophysical Research 107 (B11), 2304.

Dufek, J. \& Bergantz, G. W. 2005. Lower Crustal Magma Genesis and Preservation: a Stochastic Framework for the Evaluation of Basalt-Crust Interaction. Journal of Petrology 46, 2167-95.

England, P., Le Fort, P., Molnar, P. \& Pêcher, A. 1992. Heat source for tertiary metamorphism and anatexis in the AnnapurnaManaslu region Central Nepal. Journal of Geophysical Research 97, 2107-28.

England, P. C. \& Thompson, A. B. 1984. Pressure-temperature-time paths of regional metamorphisms I. Heat transfer during the evolution of regions of thickened continental crust. Journal of Petrology 25, 894-928.

Fliedner, M. M. \& Klemperer, S. L. 2000. Crustal transition from oceanic arc to continental arc, eastern Aleutian Islands and Alaska Peninsula. Earth and Planetary Science Letters 179, 56779.

Fliedner, M. M., Klemperer, S. L. \& Christensen, N. I. 2000. Threedimensional seismic model of the Sierra Nevada arc, California, and its implications for crustal and upper mantle composition. Journal of Geophysical Research-Solid Earth 105, 10899-921.

Foden, J. D. \& Green, D. H. 1992. Possible role of amphibole in the origin of andesite: some experimental and natural evidence. Contributions to Mineralogy and Petrology 109, 479-93.

Foland, K. A. \& Allen, J. C. 1991. Magma Sources for Mesozoic Anorogenic Granites of the White Mountain Magma Series, New-England, USA. Contributions to Mineralogy and Petrology 109, 195-211.

Franke, W. 1992. Phanerozoic structures and events in Central Europe. In Bundell, D., Freeman, R. \& Mueller, S. (eds) A continent revealed. The european geotraverse., 164-80. Cambridge: Cambridge University Press.

Fuchs, K., Bonjer, K. P., Gajewski, D., Luschen, E., Prodehl, C., Sandmeier, K. J., Wenzel, F. \& Wilhelm, H. 1987. Crustal Evolution of the Rhinegraben Area .1. Exploring the Lower Crust in the Rhinegraben Rift by Unified Geophysical Experiments. Tectonophysics 141, 261-75.

Green, T. H. 1982. Anatexis of mafic crust and high pressure crystallisation of andesite. In Thorpe, R. S. (ed.) Andesites : Orogenic andesites and related rocks, 465-87. Chichester: John Wiley \& Sons Ltd.

Harrison, T. M., Grove, M., Lovera, O. M. \& Catlos, E. J. 1998. A model for the origin of Himalayan anatexis and inverted metamorphism. Journal of Geophysical Research 103, 27017-32.

Harrison, T. M., Grove, M., McKeegan, K., Coath, C. D., Lovera, O. M. \& Le Fort, P. 1999. Origin and episodic emplacement of the Manaslu Intrusive Complex, Central Himalaya. Journal of Petrology 40, 3-19.

Hildreth, W. \& Moorbath, S. 1988. Crustal contribution to arc magmatism in the Andes of Central Chile. Contributions to mineralogy and petrology 98, 455-89.

Huppert, H. E. \& Sparks, R. S. J. 1988. Melting of the roof of a chamber containing a hot, turbulently convecting fluid. Journal of Fluid Mechanics 188, 107-31.

Jackson, M. D., Cheadle, M. J. \& Atherton, M. P. 2003. Quantitative modeling of granitic melt generation and segregation in the continental crust. Journal of Geophysical Research 108 (B7). 
Jaupart, C. \& Provost, A. 1985. Heat Focusing, Granite Genesis and Inverted Metamorphic Gradients in Continental Collision Zones. Earth and Planetary Science Letters 73, 385-97.

Jull, M. \& Kelemen, P. B. 2001. On the conditions for lower crustal convective instability. Journal of Geophysical Research-Solid Earth 106, 6423-46.

Kagami, H., Ulmer, P., Hansmann, W., Dietrich, V. \& Steiger, R. H. 1991. Nd-Sr isotopic and geochemical characteristics of the Southern Adamello (Northern Italy) intrusives: Implications for crustal versus mantle origin. Journal of Geophysical Research 96, $14331-46$.

Kavanagh, J. L., Menand, T. \& Sparks, R. S. J. 2006. An experimental investigation of sill formation and propagation in layered elastic media. Earth and Planetary Science Letters 245, 799-813.

Kerr, A. \& Fryer, B. J. 1993. Nd Isotope Evidence for Crust Mantle Interaction in the Generation of a-Type Granitoid Suites in Labrador, Canada. Chemical Geology 104, 39-60.

Kistler, R. W., Chappell, B. W., Peck, D. L. \& Bateman, P. C. 1986 Isotopic Variation in the Tuolumne Intrusive Suite, Central Sierra-Nevada, California. Contributions to Mineralogy and Petrology 94, 205-20.

Kistler, R. W. \& Peterman, Z. E. 1973. Variations in Sr, Rb, K, Na, and Initial Sr-87-Sr-86 in Mesozoic Granitic Rocks and Intruded Wall Rocks in Central California. Geological Society of America Bulletin 84, 3489-511.

Liu, J., Bohlen, S. R. \& Ernst, W. G. 1996. Stability of hydrous phases in subducting oceanic crust. Earth and Planetary Science Letters $143,161-71$.

Lucassen, F., Trumbull, R., Franz, G., Creixell, C., Vasquez, P., Romer, R. L. \& Figueroa, O. 2004. Distinguishing crustal recycling and juvenile additions at active continental margins: the Paleozoic to recent compositional evolution of the Chilean Pacific margin (36-41(circle)S). Journal of South American Earth Sciences 17, 103-19.

McKenzie, D. 1984. The generation and compaction of partially molten rock. Journal of Petrology 25, 713-65.

Müntener, O., Kelemen, P. B. \& Grove, T. L. 2001. The role of H20 during crystallization of primitive arc magmas under uppermost mantle condition and genesis of igneous pyroxenites: an experimental study. Contribution to Mineralogy and Petrology 141, $643-58$.

Mysen, B. O. 1981. Melting curves of rock and viscosity of rockforming melts. In Touloukian, Y. S., Judd, W. D. \& Roy, R. F. (eds) Physical Properties of rocks and minerals. McGraw-Hilll CINDAS. Data series on material properties 2, 361-407.

Patiño Douce, A. 1999. What do experiments tell us about the relative contributions of crust and mantle to the origin of granitic magmas? In Castro, A., Fernandez, A. \& Vigneresse, J. L. (eds) Understanding granites: Integrating new and classical techniques. Geological Society, Special Publication 168, 55-76. London: The Geological Society.

Patiño Douce, A. E. 1997. Generation of metaluminous A-type granites by low-pressure melting of calc-alkaline granitoids. Geology 25, 743-6.

Petford, N. 2003. Rheology of granitic magmas during ascent and emplacement. Annual Review of Earth and Planetary Sciences 31, 399-427.

Petford, N. \& Atherton, M. 1996. Na-rich partial melts from newly underplated basaltic crust: The Cordillera Blanca Batholith, Peru. Journal of Petrology 37, 1491-521.

Petford, N. \& Gallagher, K. 2001. Partial melting of mafic (amphibolitic) lower crust by periodic influx of basaltic magma. Earth and Planetary Science Letters 5983, 1-17.

Petford, N., Kerr, R. C. \& Lister, J. R. 1993. Dike Transport of Granitoid Magmas. Geology 21, 845-8.

Quick, J. E. S., Sinigoi, S. \& Mayer, A. 1994. Emplacement dynamics of a large mafic intrusion in the lower crust, Ivrea-Verbano zone, Northern Italy. Journal of Geophysical Research 99, 21559-73.

Raia, F. \& Spera, F. J. 1997. Simulation for the growth and differentiation of continental crust. Journal of Geophysical Research 102, $22629-48$.
Reid, J., John, B., Evans, O. C. \& Fates, D. G. 1983. Magma mixing in granitic rocks of the central Sierra Nevada, California. Earth and Planetary Science Letters 66, 243-61.

Roberts, M. P. \& Clemens, J. D. 1993. Origin of High-Potassium, Calc-Alkaline, I-Type Granitoids. Geology 21, 825-8.

Ruppert, S., Fliedner, M. M. \& Zandt, G. 1998. Thin crust and active upper mantle beneath the Southern Sierra Nevada in the western United States. Tectonophysics 286, 237-52.

Rushmer, T. 2001. Volume change during partial melting reactions: implications for melt extraction, melt geochemistry and crustal rheology. Tectonophysics 342, 389-405.

Saint-Blanquat (de), M., Law, R. D., Bouchez, J. L. \& Morgan, S. S. 2001. Internal structure and emplacement of the Papoose Flat pluton: An integrated structural, petrographic, and magnetic susceptibility study. Geological Society of America Bulletin 113, 976-95.

Shaw, H. R. 1985. Links between magma-tectonic rate balances, plutonism, and volcanism. Journal of Geophysical Research 90, $11275-88$.

Sisson, T. W., Grove, T. L. \& Coleman, D. S. 1996. Hornblende gabbro sill complex at Onion Valley, California, and a mixing origin for the Sierra Nevada batholith. Contributions to Mineralogy and Petrology 126, 81-108.

Sisson, T. W., Ratajeski, K., Hankins, W. B. \& Glazner, A. F. 2005. Voluminous granitic magmas from common basaltic sources. Contributions to Mineralogy and Petrology 148, 635-61.

Topuz, G. I., Altherr, R., Schwarz, W., Siebel, W., Satır, M. \& Dokuz, A. 2005. Post-collisional plutonism with adakite-like signatures: the Eocene Saraycik granodiorite (Eastern Pontides, Turkey). Contributions to Mineralogy and Petrology 150, 441-55.

Turner, S. \& Foden, J. 1996. Magma mingling in late-Delamerian A-type granites at Mannum, south Australia. Mineralogy and Petrology 56, 147-69.

Turner, S. P., Foden, J. D. \& Morrison, R. S. 1992. Derivation of Some A-Type Magmas by Fractionation of Basaltic Magma - an Example from the Padthaway Ridge, South Australia. Lithos 28, 151-79.

Wenzel, F. \& Brun, J. P. 1991. A Deep Reflection Seismic Line across the Northern Rhine Graben. Earth and Planetary Science Letters 104, $140-50$.

Wernicke, B., Clayton, R., Ducea, M., Jones, C. H., Park, S., Ruppert, S., Saleeby, J., Snow, J. K., Squires, L., Fliedner, M., Jiracek, G., Keller, R., Klemperer, S., Luetgert, J., Malin, P., Miller, K., Mooney, W., Oliver, H. \& Phinney, R. 1996. Origin of high mountains in the continents: The southern Sierra Nevada. Science 271, 190-3.

Whalen, J. B., Currie, K. L. \& Chappell, B. W. 1987. A-Type Granites-Geochemical Characteristics, Discrimination and Petrogenesis. Contributions to Mineralogy and Petrology 95, 40719.

White, S. M., Crisp, J. A. \& Spera, F. J. 2006. Long-term volumetric eruption rates and magma budgets. Geochemistry, Geophysics, Geosystems 7, doi:10.1029/2005GC001002.

Wood, B. J. 2004. Melting of Fertile Peridotite With Variable Amounts of $\mathrm{H}_{2} \mathrm{O}$. In Sparks, R. S. J. \& Hawkesworth, C. J. (eds) The States of the Planet: Frontiers and Challenges in Geophysics, 69-80. Washington, DC: American Geophysical Union.

Yoshino, T. \& Okudaira, T. 2004. Crustal growth by magmatic accretion constrained by metamorphic P-T paths and thermal models of the Kohistan arc, NW Himalayas. Journal of Petrology 45, 2287-2302.

Yoshino, T., Yamamoto, H., Okudaira, T. \& Toriumi, M. 1998. Crustal thickening of the lower crust of the Kohistan arc $(\mathrm{N}$. Pakistan) deduced from $\mathrm{Al}$ zoning in clinopyroxene and plagioclase. Journal of Metamorphic Geology 16, 729-48.

Zandt, G., Gilbert, H., Owens, T. J., Ducea, M., Saleeby, J. \& Jones, C. H. 2004. Active foundering of a continental arc root beneath the southern Sierra Nevada in California. Nature 431, 41-6.

CATHERINE ANNEN, Section des Sciences de la Terre, Université de Genève, 13 rue des

Maraîchers, 1205 Genève, Switzerland.

e-mail: catherine.annen@terre.unige.ch

JONATHAN D. BLUNDY AND R. STEPHEN J. SPARKS, Department of Earth Sciences, University of Bristol, Bristol BS8 1RJ, UK.

MS received 15 February 2006. Accepted for publication 3 April 2007. 